\title{
9 \\ Of kinships and other things: T. G. H. Strehlow in Central Australia
}

\section{Diane Austin-Broos}

Theodor George Henry (T. G. H.) Strehlow, son of German-born missionary Carl Strehlow and his wife, Friedericke, was born at Hermannsburg, Northern Territory, on 6 June 1908. Following the death of Carl in 1922, T. G. H. Strehlow's mother took her son to reside in Adelaide, where he attended the Lutheran Immanuel College and subsequently completed degrees in classics and English literature at the University of Adelaide. Strehlow was an outstanding student. Thereafter he returned to Central Australia and pursued studies of Arrernte language, society and, in particular, the poetry and performance in ritual song cycles of the Arrernte and other peoples of Central Australia. The notable publications from this early research included an Arrernte (Aranda) grammar in 1944 and a study of cosmology, ritual and related social organisation entitled Aranda Traditions, in 1947. Late in 1946, T. G. H. became a patrol officer in Central Australia-'the first full-time Commonwealth public servant dedicated to Aboriginal affairs' (Jones 2002). Along with Pastor Friedrich Albrecht at the Hermannsburg Mission, Strehlow was a strong advocate for the Indigenous residents of Central Australia. A sense of alienation from the larger society was fuelled by prejudiced views both of his commitment to Indigenous affairs and of his German heritage. Notwithstanding this, Strehlow regarded himself as 
an Australian. T. G. H. was called up for domestic military service in 1942 and, at the war's end, he returned to academic work, first in Adelaide, and then, in 1949, at The Australian National University in Canberra. He continued his Central Australian research.

In 1947, Strehlow chaired the anthropological section of a conference in Perth convened by the Australian and New Zealand Association for the Advancement of Science. In the course of the conference, he rued the limited expertise in linguistics among Australianist anthropologists. Subsequently, Professor A. P. Elkin of the University of Sydney proposed that T. G. H., in turn, extend his knowledge of anthropology—a discipline he had not studied formally. Strehlow went to the London School of Economics (LSE) in the middle of 1950 and remained there until early 1952. New Zealander Raymond Firth, an eminent ethnographer in Oceania, was head of the anthropology department. Strehlow sought Firth's support in the hope that the LSE might confer on him a doctorate for his already published work. Firth, like Elkin, remained unimpressed with Strehlow's anthropology, much to Strehlow's disappointment (Hill 2002: 472-3). He returned to Australia and, in 1954, became a reader in Australian linguistics at the University of Adelaide.

Subsequently, his relations with Australian academic anthropology and its supporting research institutions became strained. Strehlow remained an outsider and tailored neither his major interests nor his analyses to the normal science of British social anthropology. He published three further major works in the postwar period: an Arrernte translation of the New Testament (in 1956); a partly autobiographical narrative pertaining to his father's death in Central Australia, Journey to Horseshoe Bend (1969); and, finally, his extraordinary Songs of Central Australia (1971), a record and analysis of Central Australian ritual songs studded with allusions to classical (Greek and Roman) myth (Jones 2002; Hill 2002). In his later years, Strehlow's view of his custodianship of Indigenous artefacts and knowledge-tantamount to that of an Indigenous ritual leadermade him a controversial figure. Notwithstanding Strehlow's seminal publications, Australianist anthropologists were often critical of his stance. He died in 1978. 


\section{Strehlow on kinship, marriage and 'social control'}

To consider Strehlow's contribution to those areas of anthropology generally described as 'kinship and social organisation', as opposed to 'myth and ritual', is also to address his status as a relative outsider. While Strehlow's research was focused on ritual dimensions of Indigenous life, kinship was central to an academic anthropology influenced most by British practice. To throw light on Strehlow's contribution therefore throws some light as well on the specificity of Australianist anthropology. A short story sets the scene.

On my return from Hermannsburg in 1990, I had a conversation with anthropologist Les Hiatt about my ongoing research. Previously, he had made me a gift of Journey to Horseshoe Bend, a book he admired, though not the missionary links of the author. In the course of our discussion, he remarked that T. G. H. Strehlow would have felt more at ease with the Australianist anthropology of the 1980s than with its counterpart in the 1950s. Hiatt was referring, I think, to the impact of the Aboriginal Land Rights (Northern Territory) Act 1976 and its tendency to foster a concern with song, ceremony and authority regarding sites—as well as a gaze concentrated on descent. Strehlow's work would act as a resource for documenting some claims under the Act. Moreover, at a time when ritual life had declined in many areas where he worked, Strehlow's records of songs and genealogical connections, as well as his detailed maps of sites, provided a useful sense of traditional relations to the land. Hiatt's contrast was between this type of 'landed' focus and an earlier one on corporate structures, kinship terminologies and marriage practices-matters addressed in Hiatt's own early work (1962, 1965, 1966; cf. 1975, 2002). More generally, his reference to the 1950s concerned a period in which anthropologists saw Indigenous social life as structured first and foremost through kinship and marriage relations-a predictable conclusion perhaps when fairly sedentary settlement life for many Aboriginal peoples in Central and northern Australia was bringing the attenuation both of hunting and gathering and of ritual (see Barnes 1963). Hiatt was proposing that notwithstanding the extensive genealogical records that T. G. H. compiled, building on his father's work, Strehlow was not first and foremost a student of kinship or social organisation. His forte, like his father's, was definitely myth, and ritual as well. 


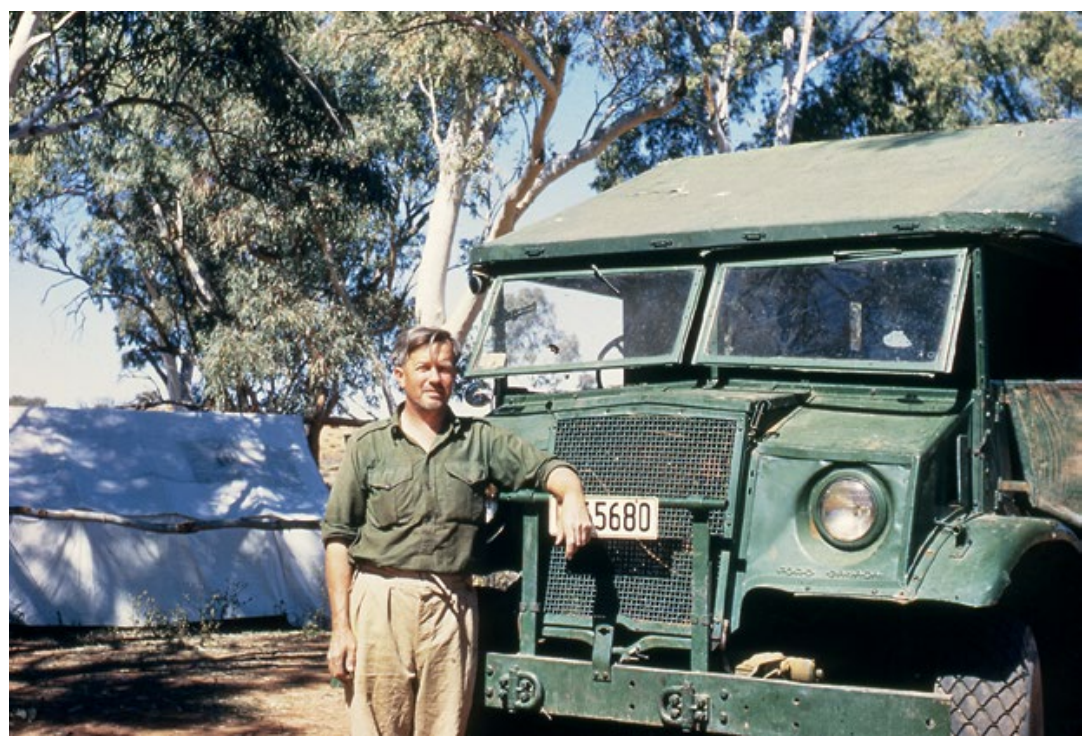

Plate 9.1 T. G. H. Strehlow with a Ford Blitz at Hermannsburg, 1960.

Source: SRC 01885, Strehlow Research Centre, Alice Springs.

Features of the Strehlow genealogies, and his essays on kinship, support this view and yet his research in this area should not be simply dismissed. Let me address the essays first and then the genealogies to put his work in context. Most of Strehlow's direct remarks on kinship and social organisation are contained in articles published in 1964 (republished 1978), 1965 and 1970, the last two in Australianist collections. Two further essays, published posthumously in 1997 and 1999, were in fact written much earlier. One, on 'social control', was composed in 1950 when Strehlow was in London at the LSE. The other, on 'regular and irregular' marriage, was undated but written soon thereafter. The 1950 paper is perhaps the most informative for Strehlow's views on units of social organisation in Central Australia. He discussed just two: the 'family', by which he meant a hearth group of parents and children; and the intergenerational patri-pairings, which he most commonly called 'njinay a' (-nhenge) sections. ${ }^{1}$ His treatment of the family was, if anything, Malinowskian (1913). He focused on various functions, among them

1 The Arrernte term has the sense of a 'relational' status and is used more commonly as a suffix for terms that describe dyadic kin relations both within and between generations. But, for this particular word, throughout this chapter, I have employed a more contemporary orthography. Strehlow's spelling of this particular term will be the more familiar to some readers. For my comment on the use of Arrernte orthographies as scholarly tools, see Austin-Broos (2009: 273). 
nurturance, education (childrearing) and marriage customs, including love magic and the chastising of reluctant brides. The kin composition of this domestic group was assumed to be more or less nuclear. Despite the fact that in the 1950s Strehlow used the term 'clan' and once remarked that his njinana section was the equivalent of Radcliffe-Brown's 'patrilineal horde', his approach to the patri-pairings was circumspect (Strehlow 1999: 40; Radcliffe-Brown 1930-31). He underlined that they were 'small' social units and designated these father-child relations in terms of subsection names used in Western Arrernte marriage classificationthat is, as one among pengartelpenangke, peltharrelkngwarreye, pwerrerlel kemarre and ngalelmpetyane. His emphasis was more on a dyad than on lineal relations, although he may have tried to present his material, with its reference to Radcliffe-Brown, in terms of known sociological categoriesfor a London audience perhaps. Whether or not he distinguished between a corporate group and a residential one is unclear. ${ }^{2}$ Consistent with his focus on dyadic relations though, he rightly repudiated Mathews's view that the intergenerational links between women in a subsection system constitute a matriline (Strehlow 1999: 41; Mathews 1907).

The 1950 paper is interesting in a further respect. In his narrative concerning one man's ritual path, Strehlow gave an account that is the closest I have noticed in his work to an ego-centred field of kin. He described relatives that fell under various subsections from the point of view of Nathanael Rauwiraka, an Ellery Creek pengarte man. To offer a sample of his remarks:

Rauwiraka ... regards all people who live in other pengarte-penangke ... areas as people related to him patrilineally and ... as people having the same status as himself ... Since Rauwiraka's mother was a pwerrerle woman, he calls all males living in a pwerrerle/kemarre area ... mother's brothers and refers to the whole district as 'land of my [MoBrs].' Again, Rauwiraka's own wife had to be an mpetyane woman. Hence any district [so settled] was to him a district settled by potential wives, brothers-inlaw, and fathers-in-law. (Strehlow 1997: 11-12)

Strehlow goes on to remark that while pwerrerlelkemarre and ngalel mpetyane were to him melyenweke, people who supplied wives, pengartel penangke and peltharrelkngwarreye, were ilakekeye, 'us two' or 'our own mob'.

2 Scheffler (1978: 522-3) tries to get around this issue by terming these units 'patrifilial kinship groups'. 


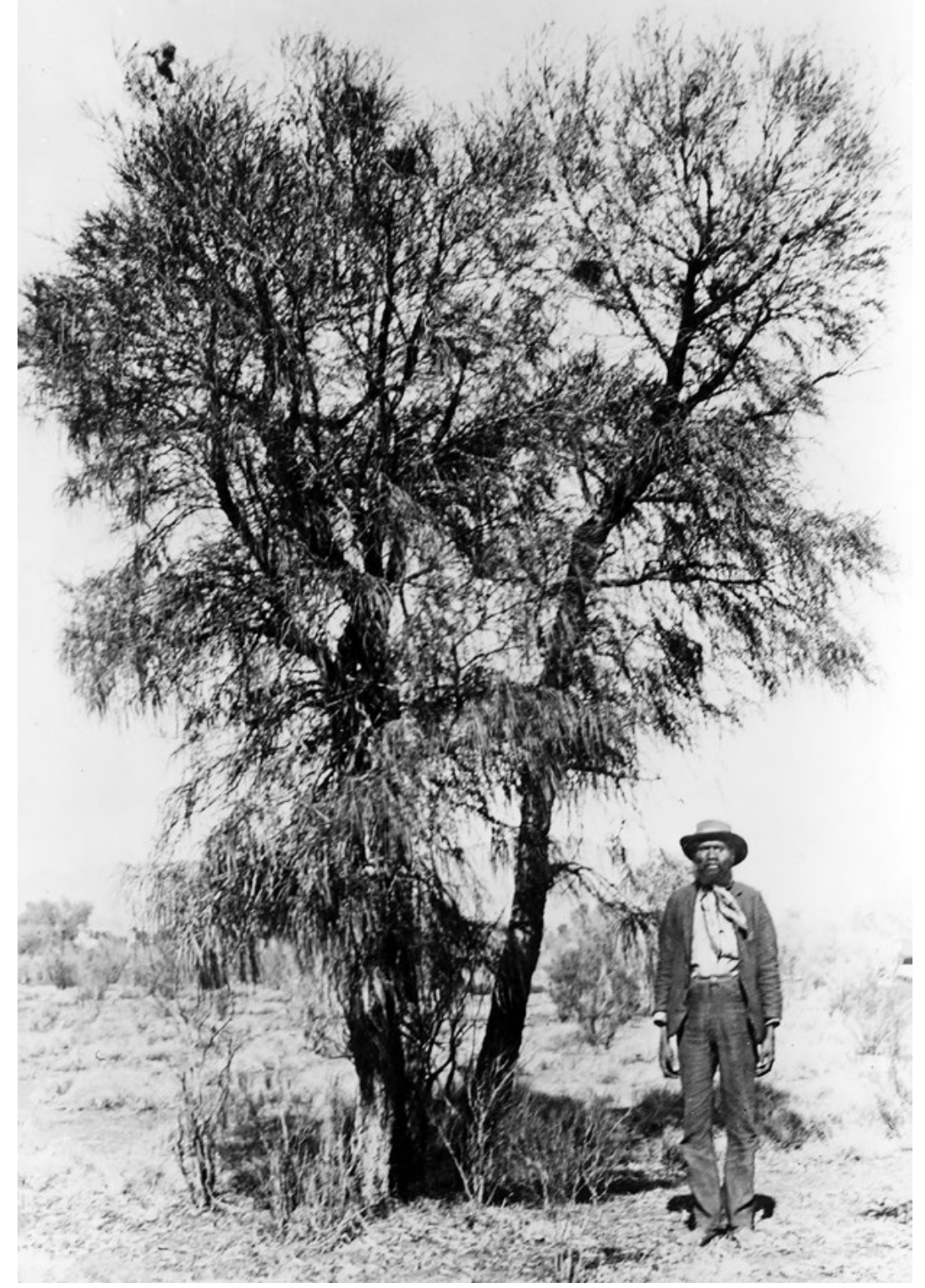

Plate 9.2 Nathanael Rauwiraka, c. 1910s.

Source: SRC 05806, Strehlow Research Centre, Alice Springs. 
In his article on marriage, Strehlow expanded. He offered a putative history of the use of subsection names to sort kin into marriage-relevant classes. He also described the way in which this system could have been embedded in 'geography'. As part of this putative history-always a precarious enterprise, from Lewis Henry Morgan through W. H. R. Rivers to the present-he indicated how this system might involve class 'shifting' with, on occasion, the re-rendering of a section as a subsection name; or an arbitrary allocation in the case of a person from the southwest where such names were not used. He remarked that the latter type of designation was done 'on the basis of physical characteristics'. 'Such men were regarded as pwerrerle if they had large heads and bushy beards; as kemarre if they had broad faces' and so on (Strehlow 1999: 21). Of these section and subsection names, which Strehlow called 'class' names, he noted that they postdated the actual classifications of a kinship and marriage system. Probably, he suggested, these summary names facilitated marriage and other forms of cooperation between different 'tribes' and 'tribal subgroups'. They acted to standardise 'social behaviour over the whole of Central Australia' (Strehlow 1999: 21).

Laurent Dousset (1999) points out that, in fact, Strehlow's treatment of so-called irregular marriages, which involved bringing new people into the system and turning to lesser preferences, not least when wives were scarce, constituted a 'new approach' to kinship and marriage. In this approach, 'contextual strategies are not seen as a deviation' from a normative kinship model. Regular variations in practice do not necessarily contradict an ideal statement of a marriage rule. Dousset (1999: 46) notes that this treatment preceded Hiatt's, which came in the form of a study of 'disputes' around bestowal caused by wife scarcity. Both preceded David Schneider's (1968: 4-8) view that situational practice need not undermine a 'cultural' unit of kinship. Strehlow was clear throughout his discussions that the Western Arrernte subsections were a system of classification and that the moieties they defined were simply named categories of people, not social groups and definitely not corporate ones. They were not a 'tribal structure'. Moreover, in these two early papers, Strehlow emphasised that this social system was sustained between multiple quite small groups stretched across a region. One might add that the patrifilial relatives involved (not the only members of these residential groups) shared alternating subsection names with the estate or country they called their 'own' place. As Morton has shown, all these classifications can 'shift' through time (see Morton 1997). 


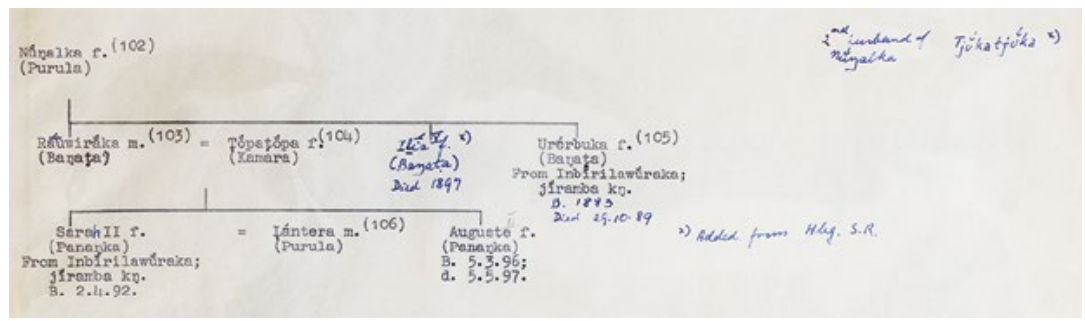

Plate 9.3 Excerpt of Nathanael Rauwiraka's genealogy.

Source: SRC FT I, 8, p. 13, Strehlow Research Centre, Alice Springs.

In the essays published before and after Strehlow's death, two things stand out. First, his discomfort with a specifically kinship account of the Western Arrernte's regional system. The songs in Rauwiraka's knowledge portfolio were by no means all acquired through kinship links; they were sometimes acquired at sites beyond the section/subsection regions. In the 1950 paper, and under the eye of Raymond Firth at the LSE, Strehlow made the following somewhat testy remark:

Throughout this account it may seem to a social anthropologist that an altogether unbalanced emphasis has been laid on the importance of religion and ritual in native society. It is, however, an emphasis made by the natives themselves. (1997: 37; emphasis added)

This was his general conclusion from a more specific argument that the complete dependence upon one another of the various totemic clans both in their marriage arrangements and in their ceremonies' was the product of an environment where people lived 'in small groups scattered over a vast land' (Strehlow 1997: 36, 37). In a 1970 version of this point, Strehlow wrote that 'social control' and 'law and order' were ensured by notions of 'totemic landscape' anchored in a 'geographic environment'. Therefore, he suggested:

[I]t is ... all the more surprising that ... so little attention has been given ... to the plotting of accurate maps ... and [to] listing the Aboriginal place-names, accompanied by detailed notes [of the latter's] totemic significance. (Strehlow 1970: 92) 


\section{The Strehlow genealogies}

The curious documents that are the Strehlow genealogies—inherited by T. G. H. from his father, Carl, ${ }^{3}$ and to which he added-became the repository for these data pertaining to a regional system. As anyone familiar with these documents would know, a majority of entries done or redone by T. G. H. involve the name of a person, a section or subsection name, the name of a conception site and the relevant conception or personal totem. In prolific footnotes to each genealogy, written in Arrernte, English or German, and sometimes scribbled or pasted on to parts of a genealogy itself, additional information is given. It may bear on the exact location of a conception site, on connections across genealogies, marriage details, conversations had or precis of police reports. Some entries also contain the colour shade or so-called caste of a person.

Further to the point that Strehlow resisted understanding a Western Arrernte system first and foremost in kinship terms, these records diverge markedly from the genealogies of British structuralism. The latter could serve two types of role. One was to show the contours of a kinship terminology and practice, the point being that kinship as such is a system of social relationships that renders or interprets biology. As Fortes (1970: $43-4,46,60)$ puts it, these renderings or 'recognitions' must be 'bodied forth' in 'objects and places' and in 'words, acts, ideas, attitudes, rules and sanctions'. Hence, the revelation of 'classificatory' kinship systems in which, for example, siblings of the same sex in a parental generation share terms translated as 'mother' and 'father' while siblings of the opposite sex are differentiated. The children of these siblings are classified accordingly. Parallel cousins are classified as siblings while cross-cousins are differentiated. Parallel cousins call both a mother and her sisters by the term translated as 'mother'; similarly, a father and his brothers are all called 'father'. This particular system is known as 'bifurcate merging', and, of course, there are a number of such classificatory systems known to anthropologists. ${ }^{4}$ Strehlow knew about such things and the Arrernte kinship terms (which involve bifurcate merging) are recorded in his

3 The original genealogies are included in Strehlow (1999).

4 Lewis Henry Morgan is credited with an early appreciation of this phenomenon (see Fortes 1970). An excellent, very short introduction to the significance of kinship terminologies is Buchler and Selby (1968: 1-8). 
dictionary. But they were not his concern in these genealogies, which were gathered mainly secondhand from senior Arrernte men. They have no 'ego' reference point.

The genealogies are named-often with reference to a deceased socially significant person. Sometimes this will be an apical ancestor, but not always. Nonetheless, all genealogies are anchored with reference to an apical ancestor or a small set of ancestral siblings. Carl Strehlow called them 'family trees' - a term that remains on the documents today. Moreover, introducing his essay on 'social control', T. G. H. remarked that all societies are interested in 'land and property'. Accordingly, these charts present as shallow family trees of five or fewer generations, informed by European notions of descent and relying on a naturalised, biological grid (see Morgan 1877; Maine 1861). ${ }^{5}$ One might conclude that they were meant to demonstrate a jural structure such as lineage segmentation-the formation, over time and across a domain, of related corporate groups with inherited rights and reciprocal roles. Strehlow's remarks on the interdependence of 'clans' seem to suggest this.

Yet, the genealogies no more address corporate groups than they address kinship as such. They do not record the patrifilial inheritance of ritual status but rather the more variable conception sites and 'personal' totems that, as Strehlow (1947: 139) notes in Aranda Traditions, were employed to distinguish between patrifilial relatives. The genealogies are notable for spread, not depth, and for their cognatic nature. Moreover, at least in the larger genealogies, they seem to aim for inclusiveness. Elsewhere, T. G. H. remarked that the conception totem of a person was remembered as long as the person was remembered-like a nickname (Strehlow 1955). Therefore, if one aimed to record as many sites as possible, to demonstrate their density perhaps, and their implications for personal identity, one might privilege conception totems over patrifilial ones. Such an approach would also make the most of recall among a small group of ageing informants. Although my impression is that the children of male affines are more commonly recorded on another genealogy, suggesting something of a patrifilial bias, the air of cognatic inclusiveness remains.

5 In a fascinating note, Fortes (1970: 294-5, fn. 21) makes a distinction between Morgan, who suggested that material property confers status, and Maine, whose view was that status makes property significant and a matter of inheritance rather than (mere) acquisition. On the naturalisation of descent, see Schneider (1984). 
Nor do the charts reflect the way in which Western Arrernte 'talk' filiation today. In a land claim context, the common refrain is that 'father's side is stronger'. In daily conversation, though, the more usual starting point is two or more consociates for whom a person wishes to demonstrate the relevant kin connection that makes them 'same family': same Mo, $\mathrm{MoFa}, \mathrm{FaSi}$ or whatever. The lines of filiation described need not exhaust a memory and reach only to the relevant nexus. The modern term 'rame rame' (meaning 'one family') can be described in terms of multiple such filiations (Austin-Broos 2009: 133-7). These daily references are more parsimonious than either the Strehlow genealogies or Sutton's (1998) 'families of polity'. They are not intended to specify a whole. Nor do they require an opt-in/opt-out clause.

Some of these matters bear on the 'West versus the rest' debate, even back to the 'African bias'. The relevance of unilineal descent and of consequent clearly bounded groups to Aboriginal social formations has been debated over many decades (Myers 1986; Sutton 1999; Barnes 1962; cf. Strehlow 1965). But that is not my reference here. Rather, my point is that T. G. H. used these genealogies for a very particular purpose: far from an interest in renderings of biology, property or corporate groups, he was focused on a socially saturated landscape made by marriages across a region and 'bodied forth' in networks of ritual. As Fortes (1970: 101-21) would have it, reviewing Aboriginal social organisation, jural concepts such as they were revolved around marriage and 'metaphysics'. Strehlow's claims for the family trees were as a spreadsheet of desert sociality understood in these terms.

Neither of Strehlow's two extended works, Aranda Traditions (1947) nor Songs of Central Australia (1971), leads with kinship as the pre-eminent framework. The contrast with Warner's (1958), Meggitt's (1962) and Hiatt's (1965) ethnographies is marked. Each approaches kinship in a different way. Warner, mindful of Radcliffe-Brown, remarks:

The kinship system is the fundamental form into which the rest of the social organization has been integrated ... The [Murngin's behaviour] can be understood only in terms of his behaviour as a kinsman. (Warner 1958: 7)

He saw a homology between the socially defined person and an integrated kinship structure. Meggitt, more mindful perhaps of the newly minted contrast between jural and domestic aspects of kinship, struggled nonetheless with Radcliffe-Brown's 'patrilineal horde', made his major 
unit a 'community' and discussed 'the family' separately and in detailed situational terms. Hiatt focused on social dramas around bestowal and was influenced not only by Meggitt's situational ethnography, but also by John Barnes's emerging network method (Barnes 1960, 1963: 204-6). Strehlow's work fell outside this normal science of British structuralism and influenced Firth's view of him. At the LSE, Firth remarked that, from an anthropologist's point of view, language mastery did not obviate the need for 'social' (meaning 'kinship') context. In describing ceremony, Strehlow 'should have said how the various actors were related' (Hill 2002: 472-3, 478-9). Firth sidestepped Strehlow's bid for a doctorate.

The second thing that stands out in Strehlow's essays is the crossness and also the stiffness with which he addressed social organisation. In the face of a Warner (1958: 15)—who described Murngin 'institutions' in terms of patrilineal clans, moieties, phratries, tribes and economic groupsStrehlow would insist on only three such units: the tribe (a language and territorial grouping), the patri-pair based njinana section, and the family. He railed against the idea that moieties were Arrernte corporate groups in the style reported by Warner (1958: 32) for the Murngin or by Elkin (1979: 120). In the face of Meggitt's (1962: 248, 250-1) comment on the Walbiri that 'the community had ... no formal hierarchy of government', Strehlow $(1970,1997)$ was almost apoplectic in his repeated attempts not to confirm that hierarchy, but rather to explain the way in which the ritual authority of Arrernte men seeped into mundane life. Possibly, this emphasis on ritual led him to reify njinana sections in terms of bounded estates, with a main inherited site from which its patri-related custodians seldom moved, except to arrange either marriage or ceremony—so invested were they in their ritual 'property' (Strehlow 1965). John Morton (1997) has provided a cogent critique of this model, which sits awkwardly with the genealogies and rules out foraging and visits on account of kinship amity, as female aspects of a regional system. Except as brides, women barely figure in Strehlow's scheme (cf. Hamilton 1987).

Yet he did see something: a very particular social milieu linked with climate and geography. One way to approach Strehlow's view would be to observe that, in a period prior to the advent of 'alliance' theory as an alternative to 'descent', his interest in particular personnel contracting marriages that reproduced kin and ritual links distributed across a region was at odds with kinship accounts in terms of descent (also see Maddock 1972: 69-71). But this view as such does not capture Strehlow's reiterated point that marriage and its affinal links were integral to a 'totemic 
geography'. Meggitt comes closer to the point when he rereads Walbiri social organisation in terms of 'intersecting patri- and matri-lines' given spread by the marriages involved in an alternating generation subsection system (cf. Meggitt 1962, 1987). Not only did this apparatus organise life crises, it also assimilated groups and individuals to places in the landscape. All three had subsection names. How to account for this? Meggitt's (1987: 118-20) revelation was that one should come to kinship via 'Walbiri cosmogony and cosmology'. One can only read Indigenous kinship through an understanding of how people see the world and its initial genesis. Meggitt's essay was subtitled 'Kinship systems or cultural categories?'. He also cited Peterson (1969) on female (secular) and male (ritual) principles as defining themes in Walbiri life. Not so different, one might note, from Strehlow's focus on marriage and ceremonial practice in, and interpretation of, a landscape. What Strehlow saw went beyond the terminology and the sociology of kinship, into cosmology and the very beginnings of ancestral beings, species and geography.

\section{Some other considerations}

It seems appropriate before a conclusion to mention some other implications of Strehlow's work distinct from the more analytical ones. There are few ethnographic records for an Australian Indigenous language group that can reward careful study as much as his Arrernte corpus does. Crucially, this involves considering his published work in conjunction with the genealogies and his mapping of significant sites across the Arrerntic region of Central Australia. The map included in Songs of Central Australia is impressive enough but becomes even more so when consulted in conjunction with relevant notebooks held at the Strehlow Research Centre in Alice Springs in the Northern Territory. Especially for routes along major rivers travelled mostly north and south, and sometimes east and west, the dense lists of placenames make one realise that the published map marks only a modest selection of actual named sites in an Arrernte geography. In addition, one needs to consult a family group who can guide an interested observer, also able to access the texts, in an understanding of their 'own place' and the travels back and forth to other places for betrothal, marriage, other kinship events, secular ceremony, sacred rite and hunting and foraging. It was not just that Strehlow found the kinship and structural analysis of his time unamenable. Owing to his focus on 'religion', he was also looking at something else: the embedded, landed 
nature of this social system, which the sociology within anthropology at the time could not quite grasp. At least some of the passion in his writing, it seems, came from his unusual knowledge and the difficulty he may have had in communicating it to others. The references to classical myth, the appeal to a distant gravitas in attempts to capture one geographically close but conceptually distant to all but a few professional colleagues, also may have stemmed from this difficulty. Keen (1988) presents a most able overview of Australian Aboriginal kinship studies that surveys their many, often abstract, complexities-reaching sometimes to the esoteric. With good reason, Strehlow receives just one citation. And yet his legacy has been much more.

Another contribution was to the mission at Hermannsburg. Strehlow's dictionary and translations of the Bible and liturgical works are well known. Less known is a working everyday compilation made by the mission and entitled 'The birthday book'-a document in typescript form updated from time to time. The book contains 37 'family' lists with at least five lists that involve two surnames used by relatives located at two or more different and distant places in the region. ${ }^{6}$ The birthday book is not a paired down version of the Strehlow genealogies, although significant amounts of data were clearly drawn from the genealogies begun by Strehlow's missionary father. This record is a more contemporary one, employed mostly through the mid to late twentieth century by the mission and then by non-Indigenous Lutheran personnel residing at Hermannsburg. It lists family members of the same surname most commonly across one to four generations along with their spouses. Each person's subsection is listed along with a birth date and a place of birth. Year of death is also recorded. An index of every relative, with the 'baptismal' (or first) name cited first, allows the user to crossreference a spouse's natal family. The book is an example of a mission's effort to remake an Indigenous people in terms of their own notions of naming, kinship, genealogical connection and domestic life. The provision of a first-name index also seems to imply that those using the book may likely only know an Indigenous person's first name- 'Rosie', 'Jim' or the like. This is a reflection of the asymmetrical relations in settlement life between Indigenous and non-Indigenous people. Rowse (1998: 80-91, 147-83) has written on these not so subtle forms of domination pertaining to the Arrernte at Hermannsburg.

6 This could happen when some among a group of relatives adopted an Indigenous name as a surname while others in the larger group adopted a settler name as their surname. 
The birthday book smacks of surveillance and, perhaps, of a Lutheran mission's love of lists. Nonetheless, the birthday book also records subsections and birthplaces. In a fieldwork that engaged non-Indigenous Lutherans as well as Indigenous ones, I noted that this book allowed nonIndigenous personnel to establish links and also formal distances between particular Western Arrernte-to learn a little of the Indigenous etiquette integral to everyday sociality. I, too, used the book when it was offered to me and, when I was trying to establish regional connections, consulted it in the company of Arrernte. As a European artefact, the book bears both negative and positive aspects.

So far as kinship practice is concerned, Strehlow was no ethnographer. The styles of in situ observational studies, evident in Meggitt's and Hiatt's work, were not Strehlow's interest. I have sought to underline that Strehlow's gaze was fixed on ritual and song and a regional system. Kinship analysis as practised in a mid-twentieth-century social anthropology was of interest only to the extent that it illuminated, mainly through marriage practices, this larger system. The intimacy of kin relatedness and the personae so defined through a sociality infused with kinship were not his empirical or conceptual interest. Although much transformed, it is this dimension of Indigenous life in Central Australia and elsewhere that has persisted to the present. Dramatic statements of grief and immense sorrow regarding the collapse of a magisterial system mark many of Strehlow's publications. One wonders whether or not this grief might have been mitigated had he been more engaged with, and comforted by, the minutiae of Arrernte kinship practice. Such an engagement also may have constrained his claims not only to the status of extraordinary scholar, but also to the status of an Arrernte ritual 'chief'.

\section{Conclusion}

One could interpret the Strehlow genealogies-with the songs and the extensive mapping and the ideas that inform their presentation both in charts and in texts-as an immense venture into particularism, prompted by the empirical facts. I suspect that, in part, T. G. H. saw it this way. But, of course, he was also immersed in religion-in Geist or, as Kroeber would have it, 'superstructure'. In our conversation, Hiatt noted Strehlow's orientation-not fashionable in Australia in his time, but worthy of respect nonetheless. Meyer Fortes once traced two 'lines of descent' in social anthropology's 'intellectual heritage'. One pursued 'structural concepts 
and theories'; the other, 'the facts of custom and culture'. Regarding the latter, Fortes (1970: 14) listed 'Kroeber, Malinowski and Frazer, to Tylor' and then 'to some extent Boas'; Boas only to some extent because, even more than Malinowski, he was a historical particularist interested in symbol and song but, in addition, in the ethos of a people, 'primitive' or 'civilised'. These two aspects of the 'German tradition'-historical particularism and romanticism-equally inform Strehlow's work.

\section{References}

Austin-Broos, D. 2009. Arrernte Present, Arrernte Past: Invasion, violence and imagination in Indigenous Central Australia. Chicago: University of Chicago Press.

Barnes, J. 1960. Marriage and residential continuity. American Anthropologist 62: 850-66. doi.org/10.1525/aa.1960.62.5.02a00060.

Barnes, J. 1962. African models in the New Guinea Highlands. Man 62(2): 5-9. doi.org/10.2307/2795819.

Barnes, J. 1963. Social organization: Limits of contemporary studies. In Australian Aboriginal Studies, (ed.) W. E. H. Stanner, pp. 197-210. Melbourne: Oxford University Press.

Buchler, I. and Selby, H. 1968. Kinship and Social Organization: An introduction to theory and method. New York: Macmillan.

Dousset, L. 1999. On reading T. G. H. Strehlow's Aranda Regular and Irregular Marriages'. Occasional Papers No. 2, December, pp. 45-59. Strehlow Research Centre, Alice Springs, NT.

Elkin, A. P. 1979 [1938]. The Australian Aborigines. Sydney: Angus \& Robertson.

Fortes, M. 1970. Kinship and the Social Order: The legacy of Lewis Henry Morgan. London: Routledge \& Kegan Paul.

Hamilton, A. 1987 [1980]. Dual social system. In Traditional Aboriginal Society, (ed.) W. H. Edwards, pp. 34-52. Melbourne: Macmillan.

Hiatt, L. 1962. Local organization among the Australian Aborigines. Oceania 32: 267-86. doi.org/10.1002/j.1834-4461.1962.tb01782.x. 
Hiatt, L. 1965. Kinship and Conflict: A study of an Aboriginal community in northern Arnhem Land. Canberra: The Australian National University.

Hiatt, L. 1966. The lost horde. Oceania 37: 124-8. doi.org/10.1002/ j.1834-4461.1966.tb01789.x.

Hiatt, L. 1975. Swallowing and regurgitation in Australian myth and rite. In Australian Aboriginal Mythology: Essays in honour of W. E. H. Stanner, (ed.) L. Hiatt, pp. 143-62. Canberra: AIAS.

Hiatt, L. 2002. People of the Rivermouth: The Joborr texts of Frank Gurrmanaman. Canberra: National Museum of Australia.

Hill, B. 2002. Broken Song: T. G. H. Strehlow and Aboriginal possession. Sydney: Knopf/Random House Australia.

Jones, P. 2002. Strehlow, Theodor George Henry (Ted) (1908-1978). In Australian Dictionary of Biography. Canberra: National Centre of Biography, The Australian National University. Available from: adb.anu.edu.au/biography/strehlow-theodor-gearge-henry-ted11792/text21095. Published first in hardcopy 2002. Accessed online 2 August 2015.

Keen, I. 1988. Kinship. In Social Anthropology and Australian Aboriginal Studies: A contemporary overview, (eds) R. Berndt and R. Tonkinson, pp. 79-123. Canberra: Aboriginal Studies Press.

Maddock, K. 1972. The Australian Aborigines: A portrait of their society. Harmondsworth, UK: Penguin Press.

Maine, H. 1861. Ancient Law. London: Murray.

Malinowski, B. 1913. The Family among the Australian Aborigines: A sociological study. London: University of London Press.

Mathews, R. H. 1907. Notes on some Aboriginal tribes. Journal and Proceedings of New South Wales Royal Society 1: 67-87.

Meggitt, M. 1962. A Desert People: A study of the Walbiri Aborigines of Central Australia. Sydney: Angus \& Robertson.

Meggitt, M. 1987 [1972]. Understanding Australian Aboriginal society: Kinship systems or cultural categories? In Traditional Aboriginal Society, (ed.) W. H. Edwards, pp. 113-37. Melbourne: Macmillan. 
Morgan, L. H. 1877. Ancient Society. New York: Henry Holt.

Morton, J. 1997. Arrernte (Aranda) land tenure: An evaluation of the Strehlow model. Occasional Papers No. 1, October, pp. 107-26. Strehlow Research Centre, Alice Springs, NT.

Myers, F. 1986. Pintupi Country, Pintupi Self. Washington, DC, and Canberra: Smithsonian Institution Press and AIAS.

Peterson, N. 1969. Secular and ritual links: Two basic and opposed principles of Australian social organisation as illustrated by Warlpiri ethnography. Mankind 7(1): 27-35. doi.org/10.1111/j.1835-9310. 1969.tb00383.x.

Radcliffe-Brown, A. R. 1930-31. The social organisation of the Australian tribes. Oceania 1: 34-63, 322-41, 426-56. doi.org/10.1002/j.18344461.1930.tb00003.x.

Rowse, T. 1998. White Flour, White Power: From rations to citizenship in Central Australia. Cambridge: Cambridge University Press. doi.org/ 10.1017/CBO9780511518287.

Scheffler, H. W. 1978. Australian Kin Classification. Cambridge: Cambridge University Press. doi.org/10.1017/CBO9780511557590.

Schneider, D. 1968. American Kinship: A cultural account. Englewood Cliffs, NJ: Prentice-Hall.

Schneider, D. 1984. A Critique of the Study of Kinship. Ann Arbor: University of Michigan Press. doi.org/10.3998/mpub.7203.

Strehlow, C. 1991 [1913]. The Aranda and Loritja tribes of Central Australia. Part IV, 1: The social life of the Aranda and Loritja. Translated by H. Oberscheidt. Unpublished ms.

Strehlow, T. G. H. 1947. Aranda Traditions. Melbourne: Melbourne University Press.

Strehlow, T. G. H. 1955. Collection of statistical evidence on the social organisation of a Central Australian tribe (the Aranda). Draft submission for grant of funds from the Social Science Research Council of Australia. Typescript. 
Strehlow, T. G. H. 1956. Testamenta Ljatinja. Anjkatja Arandauna Knjatiwumala. Adelaide: Council of the British and Foreign Bible Society in Australia.

Strehlow, T. G. H. 1965. Culture, social structure, and environment. In Aboriginal Man in Australia, (eds) R. M. Berndt and C. H. Berndt, pp. 122-45. Sydney: Angus \& Robertson.

Strehlow, T. G. H. 1969. Journey to Horseshoe Bend. Adelaide: Rigby.

Strehlow, T. G. H. 1970. Geography and the totemic landscape in Central Australia: A functional study. In Australian Aboriginal Anthropology: Modern studies in the social anthropology of the Australian Aborigines, (ed.) R. Berndt, pp. 92-140. Perth: University of Western Australia Press.

Strehlow, T. G. H. 1971. Songs of Central Australia. Sydney: Angus \& Robertson.

Strehlow, T. G. H. 1978 [1964]. Central Australian Religion: Personal monototemism in a polytotemic community. Special Studies in Religion 2. Adelaide: Australian Association for the Study of Religion.

Strehlow, T. G. H. 1997 [1950]. Agencies of social control in Central Australian Aboriginal society. Occasional Papers No. 1, October, pp. 1-50. Strehlow Research Centre, Alice Springs, NT.

Strehlow, T. G. H. 1999. Aranda regular and irregular marriages. Occasional Papers No. 2, December, pp. 1-44. Strehlow Research Centre, Alice Springs, NT.

Sutton, P. 1998. Families of polity: Post-classical Aboriginal society and native title. In Native Title and the Descent of Rights, P. Sutton. Perth: National Native Title Tribunal.

Sutton, P. 1999. The system as it was straining to become. In Connections in native title: Genealogies, kinship and groups, (eds) J. Finlayson, B. Rigsby and H. Bek, CAEPR Research Monograph No. 13, pp. 1358. Centre for Aboriginal Economic Policy Research, Canberra.

Warner, W. L. 1958 [1937]. A Black Civilization: A social study of an Australian tribe. New York: Harper \& Brothers. 
This text is taken from German Ethnography in Australia, edited by Nicolas Peterson and Anna Kenny, published 2017 by ANU Press, The Australian National University, Canberra, Australia.

dx.doi.org/10.22459/GEA.09.2017.09 